\title{
The Beautiful Blue Danube and the Accursed Black Mountain Wreath: German and Austrian Kulturpolitik of Knowledge on Southeast Europe and Albania
}

\author{
Von Albert Doja
}

\begin{abstract}
In this paper I aim to contribute to the debate about hegemonic relations between the West European "core" and Southeast European "margins", by showing the links between mutually challenged and engendered quasi-anthropological traditions in the totalitarian projects of nation-building and empire-building. New aspects of a continuous resonance will be addressed regarding a politically instrumentalized German-writing tradition of Volks- and Völkerkunde grounded in Herderian Romanticism and the imperial ambitions of the nineteenth century. In the course of discussion, the successive German traditions of National-Socialist Volkskunde and Communist East German Ethnographie until the revised tradition of Europäische Ethnologie in the $1990 \mathrm{~s}$ are shown to operate from a historicist tradition rather than from a critical tradition as a reflexive successor to former Volkskunde. In this discussion particular attention is given to contextualizing the historical and current production of knowledge by the German and Austrian "West" on a Southeast Europeanand Albanian culture, which is reduced to its archaic or pre-modern "traditions" and its specific or antiquated "mentalities".
\end{abstract}

\section{Introduction}

This paper stems from a question on the mainstream and dissident scientific networks between Southeast Europeand Germany, formulated with an invitation to give a presentation at a conference sponsored by Deutsche Forschungsgesellschaft in September 2012 at Humboldt University in Berlin. ${ }^{1}$ The focus on the history of institutions, the careers of particular individuals, intellectual biographies, trajectories and followers is crucial to understanding scholarly networks between mainstream German-speaking areas and peripheral local traditions. The number of solid studies that address the ideological foundations of scholarly production on Southeast Europe is also in steady rise at least since the $1990 \mathrm{~s}$. The critical handling of ethnographic-historical sources and the actual contributions produced within certain methodological and theoretical frameworks involving German-writing intellectual influence may also be of equal importance. In this article, the critical review of scholarly production is aimed at offering a reconstruction of the shifting ideological foundations of the cultural particularism and cultural determinism in the writings of German-speaking scholars on Southeast Europe, especially on Albania and the Albanians.

The German tradition or paradigm of Volkskunde is forwarded as an illustrative case of the politics of knowledge in the area of Albanian studies, offering a revised account of the history of German-writing scholarship known as Albanologie, especially works related to folkloric tradition, anthropology, history, philology, archaeology and related disciplines. Surely, this does not mean that a "German-writing point of view" in the development of Albanian studies can be reduced to a simple metaphorical expression for understanding "cul-

1 An earlier version of this paper was first presented to the conference on "Mainstream and Dissident Scientific Networks between the Balkans and Germany", Humboldt University Berlin, 20-22 September 2012 (Video at http://youtu.be/jLZgUQlBSjE). I benefitted greatly from the presentations, discussions, comments and encouragements of all participants, as well as from numerous friends and colleagues who have read parts of this paper at various stages and have helped to improve my argument: Enika Abazi, Chris Hann, Christian Giordano, Andre Gingrich, Klaus Roth, Sevasti Trubeta, Kurt Gostentschnigg, Stephane Voell, Christian Promitzer, Christian Voss, Ioannis Zelepos. I am also very grateful to the anonymous reviewers for their insightful comments and recommendations. 
ture" in terms of Volksgeist. This might be "common sense in many cultures and among many scholars of different national traditions irrespective of their nationality and the language of their writings", as one anonymous reviewer seemed to assume while warning against the risk of homogenizing the various influences of German-writing scholars on Albanian studies that could disregard their differences and historical peculiarities over a century of scholarship. ${ }^{2}$ If the discussion is aimed to contribute to the debate about hegemonic relations between the West European "core" and Southeast European "margins", it is necessary to contextualize the disguised "supra-colonial", "crypto-colonial" or "self-colonizing" conditions (Pandolfi 2000; Herzfeld 2002; Kiossev 2011), some new words for the old concepts of internal colonialism, post-colonialism or neocolonialism, which I also showed elsewhere to have permeated the public life in Albania and Kosova (Doja 2001). Such a contextualization is crucial in the historical as well as in the current production of any knowledge at a given time, in a given place, and for some given purpose. This can be highly suggestive in understanding how Western colonialism maintained and continues to maintain a surprising degree of cultural and political influence far beyond its official spheres of power.

The anthropological traditions in Germany, Austria and the German-speaking parts of Switzerland cannot be treated independently before the $1960 \mathrm{~s}$. The Austrian academia had always been an integral part of the German-writing scientific world and mutual exchanges of scientific and academic personnel between German, Austrian and Swiss institutions were frequent. Most leading members of the early-to-mid twentieth-century Vienna school of anthropology were German priests, most prominent German anthropologists were Austrian by birth and by academic education, and key figures in twentieth-century Swiss anthropology were also German or Austrian citizens. The aim of this paper is not, however, to offer a contextualized historical view and of the different intellectual productions of German-writing scholarship in Albanian studies, neither to exhaustively treat each of them on their own.

Depicting the different methodologies and approaches that distinguish academic traditions in a given society is certainly useful. It is perhaps even more important, and at once more problematic, to reveal the different political, social, ideological and cultural implications of various traditions. However, I am not pitted between a historical strand in its own right and another concerned with the present uses of the past, or to use George Stocking's opposition between "historicist" and "presentist" analyses (Stocking 1965). Rather than leaning towards either presentism or historicism, my concern is to concentrate on the intellectual history of ideas, methods and contributions, through the mixing of historicism with a degree of a more frankly presentism in which the "German-writing point of view" is reexamined for its contemporary uses.

Taken together, a critical reassessment of these strands may contribute to present debates within anthropology. If anthropology is to emerge and persist as a viable field, in Albanian studies as elsewhere, it needs to attend more carefully to its own social reproduction. As with German-writing "nontraditions" more specifically (Gingrich 2005), the task is therefore not to simply summarize previous and established insights and opinions, but rather to question those previously established opinions that today seem to be one-sided or condemnable. Ultimately, we need to consider how to engage constructively with the past in ways that may develop a vision for a renewed anthropology within Albanian studies from the perspective of those presentist, critical, and internationally oriented positions that we need to strengthen and promote today.

2 A more extended version of this paper addresses elsewhere the more specific aspects of the continuous influence of the German-writing traditions of Volkskunde on the native Albanian tradition of "folk" or people's culture studies (kultura popullore) (Doja 2014). 


\section{The birth of Volks- and Völkerkunde}

Beginning in the $1830 \mathrm{~s}$ and accelerating after the emergence of the German nation state in 1871, nationalism increasingly was instrumentalized as a force serving dominant Prussian interests, while German Volkskunde was acquiring socio-political significance in the quest to bind together the country's previously fragmented regions. After the historiographic and historicist school of writing history superseded philosophy to become the dominant force in the Geisteswissenschaften throughout the nineteenth century and thereafter, Volkskunde became an integral part of German historicism (Gingrich 2005). In association with the development of ancient art history and Germany's pronounced "cultural obsession" with the glories of antiquity, and the subsequent establishment of exacting standards of scholarship in allied disciplines under historicist hegemony such as Altertumskunde and comparative philology, German Volkskunde became established as the historicist study of a superior Germanic self. Its practitioners were in charge of proving common archaic origins, the evidence of which was to be found in Volkskultur, thus revealing the Herderian Volksgeist set apart from the study of the Herderian Naturvölker (Stocking 1996).

German Volkskunde was aimed to uncover an older and unsullied state of the German people's culture and spirit (Volksgeist). This does not only mean a shared acceptance of Aryanist theses emanating from the groves of German academe to uncover august antiquity and cultural dignity. Above all these studies inevitably acquired both a methodological descriptivist orientation and a political nationalist attitude. Their methodology is based on folkloric data collection to celebrate a national model that is supposed to be deeply rooted in the past, which can be traced back to Herder's perspective on culture (Sundhaussen 1973) and other German romantic reactions to the universalism underpinning French enlightenment. This culturalist and historicist tradition has been institutionalized as "a deliberate, organized, conscious effort to construct a more satisfying culture" by what is known as a "revitalization movement" (Wallace 1956: 265).

People's culture studies in the Volkskunde tradition were oriented towards one's own culture and cultural details, towards the search for authenticity or antiquity of customs and cultural values of a given society, which is one's own society. This fact bears in itself important political and ideological implications. The folklorist framework of such approaches can hardly be considered a methodological framework or a disciplinary approach. Often transformed into a passion for local or national cultures, they can exceed simple collecting, conservation and study approaches. They become practices of cultural manipulation, a kind of "Fake-Lore" or "Folklorismus", the term used to refer to the voluntarist "invention of tradition" (Hobsbawm / Ranger 1983). As such, they include the performing, staging and adaptation of any element of a tradition or folklore outside the cultural context in which it was created, often implying changes in form, meaning, and intended goals of actors. This attitude is particularly likely to be entangled with nationalism and totalitarianism. This entanglement can be inadvertent and unintentional. Yet, depending on countries, political regimes and ideologies, as the specific cultural practice of folklorism in the heyday of Nazi German Volkskunde clearly showed, such a folklorist framework often becomes, deliberately and intentionally, the prey and fuel of political ideologies stemming from nationalistic claims or totalitarian regimes.

The tradition of Volkskunde took shape in the historically determined political, economic, social and cultural conditions when the German national state was created. These conditions were creating a burning feeling of national resentment and a climate that was extremely favourable to the production of all-encompassing ideological solutions, which led German intellectual elites to consider Romantic nationalism a viable strategy of overcoming the his- 
torical problems their group was faced with (Greenfeld 1992). As a nationalist ideology, Romanticism started with German national resentment giving birth to Pan-Germanism.

All this could not but bring about the interest in the collection, description, conservation, and often exaltation of German culture altogether with the "scientific" ideal of a nationbuilding discipline. Much the same as is generally the case with any native studies that are at once advocacy studies, Volkskunde was institutionalized at a time of national movement and state building. The desire to stand out from neighboring countries and the aggressive promotion of claims to civilizational superiority and antiquity were, and still are, the characterizing features of studies in the Volkskunde tradition. In these situations, almost naturally, a science or a group of sciences is needed that could perform tasks of "national" importance to confirm that there really existed a nation, and that in its pretensions to an independent state the nation had a continuity of territorial possession and a historical legality or at least cultural legitimacy.

Turned into a weapon of politics and national pride, the task of these studies became to enforce identity construction by providing the proof of national cultural unity over heterogeneous local communities. They located, with varying degrees of success, the nation's essential continuity from antiquity to the present. They insisted on the nation's superiority in autochthony and uniqueness over rival neighbouring cultures as an indispensable element for a prestigious image of national identity. They became a nation-building discipline because they provided cultural and historic evidence of German existence, distinction, prestige and legitimacy as a confirmation of "scientific" ideals. These principles were at work in Altertumskunde and Volkskunde, which were perceived primarily as "national" sciences that were supposed to uncover the Volksgeist and contribute to understanding of "us" as superior to "them". In a general way, the influence exercised by these ways of thinking has long encouraged official people's culture studies throughout Europe to interpret cultural difference in terms of hierarchy (Bausinger 1993).

The main studies in the Vokskunde tradition were clearly caught up in celebrations of the nation, and blanket allegations of being a "nationalist discipline" are normally heard of. Indeed, it was not surprising to see scholars, writers, literary theorists and critics launching and conducting debates on German "psychology" and the "national soul", mixing within their arguments "German" glorious past, cultural heritage, folk culture, ethnic territory, the principle of "blood" or racial traits. Questions of language, philology, folklore, customs and traditions for long have provided the core arguments for the great debate on modernity. Folklore and the discourse on Volkskultur and "folk ways of life" have contributed to the essentialization of the national character, thus providing arguments for nationalism.

Similarly, on the formal and institutional level, the academic establishment of German Völkerkunde was caught up with national interests in the context of Prussian emergence as an imperial power with colonial ambitions in Europe (Zimmerman 2001). While the initial motives were channeled and shaped by various contexts (Penny / Bunzl 2003), the research projects of its practitioners were strongly embedded in the objectifying exoticism of folkloric museum displays, adventurist reports and voyeurist exhibitions (Völkerschauen) of an aggressive colonialist newcomer.

Both Völkerkunde and Volkskunde derived from a historicist and museum-oriented tradition in which Völkerkunde dealt with the culture history of external others and Volkskunde with the historical others of the national cultural tradition. More than a simple demarcation between them, a complementary division of labor is assumed, both having contributed to the construction of "Other", both inside and outside Europe. They did not develop during a time of imperial expansion like ethnology in France and anthropology in Britain but during a time 
of imperial aspiration. If in the national context the historicist model for Volkskunde led to Herder's notion of Volksgeist, in the new colonial context the natural science model for Völkerkunde led to a continued revitalization of Herder's notion of Naturvölker, natural or primitive peoples with little or no culture and no history, who thus could reveal the true nature of humans. The intensive investigations carried out along with scholars from other German-speaking countries favored a tripartite model of history and conceived local societies as Naturvölker "primitive peoples", Stammeskulturen "tribal cultures" and Volkskulturen "people's cultures". Based on the important precursors of a well-established philological and philosophical tradition, this model was informed by a more or less explicit distinction between what were considered primitive and illiterate, Oriental and literate, and modern European cultures and languages (Gingrich 2005: 69). A hierarchy in terms of developmental potential thus was explicitly introduced in this tripartite classification of history and society, which further contributed to universal typologies of hierarchical "human species" (menschliche Arten). In Germany, Austria, and many parts of East Central Europe a notion of origins thus developed, according to which humanity's "limited inventiveness" or "mental poverty" (Ideenarmut) was compelled to improve under the influence diffused from a few focal "civilizing circles" (Kulturkreise) of some given "civilized peoples" (Kulturvölker). German diffusionism thus became a genius-centered, speculative history of hierarchical cultural distributions.

In both branches of Völkerkunde and Volkskunde, German scholarship was a formidable player in the international scene, launching some of the largest anthropological expeditions, having a powerful presence at international conferences and founding a number of internationally recognized periodicals (Penny / Bunzl 2003). Heavily state-subsidized organizations and institutions as the support of "disinterested" German philanthropy abroad were meant to highlight the achievements of German scholarship. In reality, Kulturpolitik was a state policy intended to enhance German national prestige that yielded to the commanding presence of a high antiquity created in the crucible of late-eighteenth-century Aryanism. Although the German philologists and art historians who generated the Aryanist model of German culture may have not explicit racist and colonialist views, they were doing the ideological work of the supremacist project of German hegemony leading to the cultural eugenics of a Nazi "race science" (Rassenkunde). Actually, German Kulturpolitik disguised imperialist aspirations that occasionally were made explicit. In 1902, the German consul to Constantinople unequivocally qualified German archaeological policy throughout the lands of the Ottoman Empire as a gradual spiritual conquest (geistige Eroberung) of the Orient:

The interim intellectual goals already pursued, or to be pursued by our schools, our doctors and our archaeologists could very well become, in the course of time, the crystallization point onto which German economic and colonizing undertakings are grafted. The economic will follow the intellectual conquest as a natural result, and then these two diffused phases will naturally be followed by the third stage, that of political exploitation (Verwertung) and consolidation of the cultural values we have created. (Quoted by Marchand, in Stocking 1996: 318)

The colonial contributions by German and Austrian scholars may have remained fairly limited in substance and relatively heterogeneous as to their purpose and direction (Penny / Bunzl 2003: $23 \mathrm{f}$ ). However, virtually all representatives of Völkerkunde profited from and worked for colonial interests until 1918. They continued during the First World War to be actively at the service of colonialism and the imperial armies in both the German and Austro-Hungarian empires, more explicitly and more directly than did their counterparts in France and Britain (Johler / Marchetti / Scheer 2010). Many of them carried out research documentation, especially among prisoners of war and in Southeast Europe. It has been ar- 
gued that such a practice constituted one of the most decisive fields by which linguistic and ethnographic inquiries were brought together with racial studies much more closely than had been the case before. In addition, its far-reaching influence helped to refine the scientific and nationalist agendas in Central and South-East Europe (Turda 2013).

The case of Austria-Hungary clearly shows the extent to which the politics of knowledge on Southeast Europe is informed by imperial interests, even though simplified historiographic equations of Völkerkunde with colonialism and Volkskunde with nationalism do not work as easily in the Austro-Hungarian or Swiss contexts. Being developed in a context quite different from that of Germany, Austrian Völkerkunde went beyond the stereotypes and blind spots of Orientalism, while the link between Volkskunde and nationalism, so typical of the rise of folklore studies in Germany, was not possible for a scientific community aspiring to public acceptance and advancement in political entities that were quite diverse linguistically, religiously, and culturally (Gingrich 2005). Although ethnicity was a key concept, in the German-speaking parts of Switzerland and the Habsburg lands, it was understood as different from the political concept of nationality and subjection to the confederal or imperial state, while nationalism of any kind was generally dealt with as a subversive, secessionist danger.

As national folklorist movements evolved toward the end of the nineteenth century, Vienna launched a Volkskunde that had to deal with a given cultural diversity of all the peoples of the Monarchy. Specifically, in the provincial centres a diverse spectrum of academic institutions, museums, learned societies and numerous private initiatives were active in this field. Some of these had a more aesthetic, some a more academic, others yet a more political mission, not without some limited nationalist leanings in the German-speaking parts of the empire and somewhat more explicit nationalism in other, more peripheral parts. The protagonists, and at least a part of their growing support base in the bourgeoisie and aristocracy, were stakeholders in a liberalism supportive of the state. Unlike the subject populations of other empires of the time, such an approach was facilitated by the fact that the empire's various peoples were all found to belong to a common Indo-Germanic race. The "real Volk" of the Empire was conceptualized to be found underneath superficial national and ethnic differences as an underlying universal and primitive substrate.

Empathic governance was to capitalize on the cultural diversity of the empire, thus resonating with Herder's vision of humanity as existing in Einheit durch Vielfalt, which was promoted as the essence of the empire's own "unity through diversity". Translated into an implicit academic paradigm, the aesthetic refinement of this liberalism and a kind of fair trade through the consideration of traditional social structures promoted the conjunctive rather than disjunctive aspects of culture and the emergence of a less nationalist and more interculturally oriented tradition of people's culture studies. Yet, intercultural liberalism did not mean egalitarian culture. Culture was a hierarchical concept and the claim for a leading role for German culture was not questioned. Arguably, this would also mean that the evolution of Volkskunde as a discipline in Austria was much more closely related to colonial expansion than its Völkerkunde counterpart.

\section{The foundation of Albanologie}

The particular Habsburg brand of imperial expansionist energies were of short distances (Feichtinger / Prutsch / Csáky 2003), projected into the post-Ottoman territories in southeastern Europe rather than overseas. In the nineteenth-century context of the hegemony of Russia in Eastern Europe, the displacement of Austro-Hungarian political and economic interests out of Germany and Italy brought the concentration of the foreign policy of the Habsburg Monarchy on Southeast Europe as the only way to resist Panslavism and Italian imperialism. 
The Balkankommission was founded in 1897 in the Austro-Hungarian Imperial Academy and the Institut für Balkanforschung was founded in 1908 in Sarajevo at the initiative of the Austrian Foreign Ministry to face the Italian concurrence in the exploration of Southeast Europe, which must be seen as the expression of the Austrian claim to take over the leading role in the Southeast European studies that came to be branded as Balkanologie. The institutionalized of this academic formation considered Southeast Europe as an entity. It was influenced by the discursive conjunction of nationalism and linguistics and was dominated by philological approaches. The so called "Balkanologists" were mainly concerned with ethnolinguistics and historical linguistics, as Southeast European languages were still in a process of standardization along a form of linguistic nation-building. Additionally, through the dehierarchization of culture in romantic nationalism, folk literature and customs became a legitimate subject of academic research, and in the late $1800 \mathrm{~s}$ Volkskunde had become the major topical area of Balkanologie.

A premier "colonial situation" for Austria-Hungary was located in the former Ottoman provinces of Bosnia and Herzegovina occupied in 1878 and finally annexed in 1908. In the last quarter of the nineteenth century and early twentieth century, continued weakening of the political and economic position of Austria-Hungary in the other Southeast European states, which were becoming increasingly independent, induced Austro-Hungarian special interest in Albanian-speaking territory. Austria-Hungary played an important role in the formation of an Albanian independent state in 1912, while Albania was compelled to acquire political independence at the expense of massive economic dependence. The intensification of Austrian-Albanian relations in fields of politics, commerce, culture and research was intended to secure and strengthen its political, economic and cultural influence over Albania in the form of an informal imperialism based on structural violence (Gostentschnigg 1999). This was mainly achieved by means of a Kultusprotektorat over Albanian Catholics within the Ottoman Empire (Deusch 2009), by means of extensive financial support of educational and cultural activities (Ramadani 2010), and by means of the development of a subset of Balkanologie, known as Albanologie, which encompassed Volkskunde and other research on Albanian history, language and culture.

Representing a liminal region between the two approaches of Völkerkunde and Volkskunde, Southeast Europe became a key field of research for both. Their respective institutions were exploiting every possible way to systematically promote themselves as the future centres for the study and presentation of Southeast Europe. Austrian scholars of Volkskunde presented more successfully an agenda for continued research into the culture and ethnography of Southeast Europe that promised the production of knowledge that would be useful for the military, economic and political interests of Austria-Hungary (Marchetti 2013). Research and publishing activity of the Austro-Hungarian Volkskunde of Southeast Europe and Albania experienced a boom that paralleled the political interests of the Habsburg Monarchy in the area in the height of the political and commercial rivalry with Italy and in the course of the First World War with the military occupation and administration of good parts of the region between 1916 and 1918. With an implicit attempt to gain recognition by the state and realize a footing as a university discipline, Austrian Volkskunde showed an intensive interest in the studies of the occupied territories in Southeast Europe, including Albania, and scholarship went hand in hand with collaboration, if not collusion, with military occupation and political administration of these areas.

Regular research expeditions were organized by the Austro-Hungarian Academies of Sciences (e.g. Haberlandt 1917) and a number of scholars were travelling into the Albanian territories to explore the country and the people. The development of these studies aimed at inducing the preference of not only Catholics but also Muslim Albanians for the Habsburg 
Monarchy over other Powers, as they may appreciate Austro-Hungary for its interreligious tolerance and its resistance to Panslavism. As the Austro-Hungarian scholarship seemed to boost the strong sense of honor and the national consciousness of Albanians, they had to foster a sense of sympathy and gratitude toward the Habsburg Monarchy, which in turn could give Austrian interests in Albania an advantage over other political and economic competitors, including Italy. In addition, research expeditions in Albania had to provide a clear picture of the cultural, social, economic and political life, which could be exploited for investment opportunities by the Habsburg Monarchy.

In this context, a group of German-speaking writers were mobilized, mostly Austro-Hungarian and Prussian scholars with a strong interest in Albanians and their history, language and culture. Several of them shaped the founding generation of Albanian studies, or what came to be known as Albanologie in German-writing jargon. Surely, there was no concrete political programme for an instrumental research, but a generous stimulation of Albanologie and Volkskunde, so that in a more serious situation, namely the First World War, they could be put at the disposal of the Austrian state interests. Indeed, as stated by Gostentschnigg (1999: 244 f), some renowned Austro-Hungarian scholars worked in Albania both for academic research and for the policy of their country, such as the consul Johann Georg von Hahn, the secret agent Franz von Nopcsa, or the politician Ludwig von Thalloczy, while the work of many others was also exploited for political and commercial strategic objectives. Many of these scholars dealt with archaic cultural features of the Albanian society, especially concerning customary behaviour and the so-called tribal organization, or the ethnogenesis of Albanians, which included the question of the Illyrian heritage and the extent and results of successive processes of Hellenization, Romanization, Slavicization and Islamicization of present-day Albanian-inhabited areas (e.g. Thalloczy 1916). It is possible that some of their observations turned out to be wrong or misleading on further research, but their contributions still provide a short expedient for further studies by native scholars in Albania.

The importance of these scholars in the periphery of the imperial center, however few in number, together with other adventurers, travelers, traders, soldiers, and colonial consuls, can be shown not only on local people, especially the elites, but constantly in their decisive influence over imperialistic processes (Mommsen [1977]1980). Actually, a related problem with many of the writers of the old generation of Albanian studies is that they consciously or unconsciously promoted the idea that at the beginning of the twentieth century the "unknown" Albanians were still at the stage of the last "undiscovered" people in the Balkans, living in "Accursed Mountains" (Bjeshkt e Namuna) or surrounded like their fellow Montenegrins by a "Black Mount Wreath" (Crna Gorski Vijenac), ${ }^{3}$ so close and yet so far, like Greece on the southeastern "margins of Europe" (Herzfeld 1987).

As some of the new generation of German-writing scholars acknowledge (e.g. Gruber 1998; Gostentschnigg 1999; Kaser 2002; Promitzer 2012; Hemming 2012; Marchetti 2013), it was in particular the Orientalizing and Balkanizing images of old German-speaking writers who selected and reported observations almost exclusively from the northern Albanian regions that singled out certain seemingly "archaic" phenomena that were labelled and reified as "Albanian". They put emphasis on the so-called Albanian "tribes" and their primitive laws, archaic blood revenge, the primitiveness and purity of the indigenous people, spartan simplicity yet incomparable hospitality, and so on. A special genre of accounts on blood feud developed, which was inspired especially by those Austrian and German travellers whose writings, typical of a travelogue, were primarily aimed not at providing information

3 The Accursed Mountains (Bjeshkt e Namuna) is a local term for the Mountains range in North Albania, while the Mountain Wreath (Gorski Vijenac) is a masterpiece of Montenegrin literature, written and published in 1847 by the Prince-Bishop of Montenegro, Petar II Petrović-Njegoš. 
or conducting scholarly work but at sensational discoveries (Kaser 2002), brought back by the insatiable desire for acquiring artificial prestige in network ratings. According to the intention of one or another of these writers, Albanian "tribesmen" were depicted in their Accursed Mountain Wreath either as savages and barbarians or as outstanding virile and heroic "sons of the eagle". The impression is always given that people's life was concerned with blood feud and nothing else. Otherwise, a very appealing sentiment of heroism was used, in a definite tendency towards an idealization of Albanians, especially the northern mountaineers, depicting local life and customs in a heroic and glorious light, idealizing patriarchal society and its manly features, such as bravery, honour, and hospitality.

The double-edged German perceptions of the Albanians, which had been dominant since the early nineteenth century, are best encapsulated in a travel novel by Karl May (1842-1912), one of the most popular nineteenth-century German writer. ${ }^{4}$ In his Durch das Land der Skipetaren, published in 1892, the Albanians were either deemed "rooted" within their own customs in their homeland (Heimat), in which case he called them "Skipetaren" (from the Albanian self-designation shqiptar), or they were "rootlessly" dispersed through the empire (separated from their Heimat, for example, as mercenaries to the Ottoman state), in which case he called them "Arnauten" (from the Turkish ethnonym for Albanians). Here a judgmental symbolism clearly produced stereotypical imagery. The characteristics of "Skipetaren" such as physical strength, sincerity, courage, group loyalty, attentiveness, solidarity against the enemy, sometimes hospitality and loyalty to the foreigner, sometimes xenophobia, a will for independence, "the sight of an eagle", self-confidence, faithfulness to the given word, proneness to revenge, hatred, irreconcilable but honest anger, are all contrasted to the "Arnauten". These are corrupt, violent and unpredictably cruel, dirty, poor, ignorant of both state and religious law, open to bribery and prone to alcoholism, theft and murder. As in general dislocated ethnic groups provide the least sympathetic characters in Karl May's writings, the "Skipetar" in his rough and mountainous Heimat displays features that mirror the popular national-conservative German ideals of the noble savage of the time, including the quality of "legitimate" or "honourable" violence. In contrast, the "Arnauten" display all the features, which May despised and implicitly considered responsible for the decline of the Ottoman Empire.

In the aftermath of the First World War, German Völkerkunde never recovered from what led to the loss of the German colonies, destroyed the funding sources of German ethnology, and eradicated the international networks German scholars had built up over the previous four decades (Penny / Bunzl 2003). Similarly, although Austrian Volkskunde claimed scholarly hegemony in Southeast Europe, the demise of the Dual Monarchy with the First World War can be seen as the demise of the regional scope of Austrian scholarship that was compromised by a new political order (Gruber 1998). The fate of professional institutions such as the Balkan-Abteilung of the Museum für österreichische Volkskunde that became a relic of a bygone imperial past (Marchetti 2013) is indicative of what was left of the great Danube Monarchy, politically unstable, suddenly of marginal international influence, and without any of the pomp of empire. Austrian interests in Southeast Europe, including Albania, lost priority due to differing geopolitical contexts and reshaping of the state's character and size. They never totally broke down, however, while the topics of Balkanologie and Albanologie even broadened in Southeast Europe and Albania.

4 The populist and scholarly views on the Albanians synthesized in his novels are analyzed by the contemporary German historian Michael Schmidt-Neke (1994): Von Arnauten und Skipetaren: Albanien und die Albaner bei Karl May, in: Claus Roxin, H. Schmiedt and H. Wollschläger (eds), Jahrbuch der Karl-May-Gesellschaft, Husum, S. 247-284 (reported in Schwandner-Sievers 2008: 56 f). 
In this context, Albania became a refuge where one could escape the sad realities of interwar Vienna and Weimar Germany. No longer the victim of a Byronian fantasy of an untamed wildness, interwar Albania emerged as a projection screen for nostalgic fantasies of any number of disaffected Europeans, a miniature of either a great European past, or of a grand European future (Hemming 2012). Not surprisingly, the interest in Albania increasingly shifted from pure exoticism and acquired an expansionist imperial character. The production of fictional literatures set in the Balkans, featuring Balkan and Albanian protagonists, or otherwise concerned with Southeast Europe, was a means whereby the German and Austrian, like their fellow British and French, secured their stakes to supply their literary entertainment industries and their political ideologies through the "imperialism of the imagination" (Goldsworthy 1998 [2012]). Karl May's stereotypes of the rooted/uprooted divide applied to the Albanians, for instance, might have already anticipated a romantic rhetoric of Natur und Heimat, racial purity, anti-Semitism and heroic Übermenschentum, which was later reproduced in German National-Socialist encounters with Albanians (Schmidt-Neke, reported in Schwandner-Sievers 2008: 57).

During the Nazi rule, both Völkerkunde and Volkskunde went through an institutional integration into the Third Reich that was instigated from above but simultaneously found support from and was complemented by certain continuities in the public sphere where an adventurist and voyeurist exoticism of "primitive peoples" (Naturvölkern) and "people's cultures" (Volkskulturen) continued to prevail. In addition, the expansionist political and military plans of Nazi Germany's leaders definitely included a number of scenarios and plans for Germany to become again a colonial power outside Europe, which were the rationale behind serious material efforts that Nazi Germany mobilized for colonial research (Mosen 1991). However, more than anything else, the legacy of German diffusionism from the "civilizing circles" (Kulturkreise) of "civilized peoples" (Kulturvölker) and the huge research projects in race studies of imperial Germany created an established acceptance on which the German racism and genius-centered view of humanity in the first half of the twentieth century could build with their own schemes and projects, and with increasingly murderous ambition, which is especially shown in the practical involvement of both Völkerkunde and Volkskunde in Nazi Germany's colonial and holocaust programme inside Europe. ${ }^{5}$

Several cross-regional studies had already been facilitated by the Austrian Balkanbahn project in the late 19th century. Yet, German interest in economic expansion in the Großregion facilitated a surge of economic studies on the entire region, especially in the area of economic "supplementation" (Ergänzungswirtschaft), i.e. exploitation, within the framework of the Mitteleuropäische Wirtschaftstag, which from 1931 to 1944 was a Forum of German leading corporations, banks and trade associations that initially pursued the goal to win the Central European market economically and indirectly to rule it politically (Thörner 2008). Among other things, the scientific approach that was now rebranded under a more sanitized term of Südostforschung was meant to prepare and underpin spatial planning which included the deportation of large portions of diverse populations. In both cases, Austrian expertise also played a considerable role (Promitzer 2012). It also seems that the idealtypical descriptions of Albanian customary law, noble masculinity and warrior's honour might have underpinned some German Wehrmacht autobiographies from the time of occupation in Kosovo and Albania (Schmidt-Neke, reported in Schwandner-Sievers 2008: 57).

5 A number of studies have shown by now that some of the representatives of Völkerkunde carried out applied research for Nazi purposes, which would benefit from the Nazi killing machine or contribute to it (Fischer 1990; Linimayr 1994; Dostal 1994; Hauschild 1995; Streck 2000; Schafft 2004), while many representatives of Volkskunde produced explicit propaganda for the Nazi regime and elaborated its ideology by using and abusing their academic and professional authority (Emmerich 1968; Gerndt 1987; Lixfeld 1994; Dow / Lixfeld 1994). 
The contexts of the geopolitical position of the German Reich and the Habsburg Monarchy towards Albania and Southeast Europe in the decades before the First World War and the position of Germany and Austria towards this region in the interwar period and during the Second World War determined the respective activities of scientific research and the respective perceptions of public opinions. Scholars, travelers, adventurers and experts either followed or prepared the multilayered economic and political interests of their respective community.

\section{Folklorism under Socialism}

From the period of nation-building through the period of national-socialism, the most important ideological implication of Volkskunde is its being intricately linked to national politics in a function to explore and construct a particular vision of the "own" against the "other", which further lead to the subversion of scholarship into a pure instrument of politics and a field of propaganda. Soon after 1945 the most urgent task for any practitioner of the discipline in both West and East Germany was the coming to terms with the undeniable fact that their discipline was viewed as one of the most associated with the notorious ideology of German National Socialism. Even though the initial developments in the two German states were completely disparate, the reappraisal was gradually undertaken in succeeding years in relation to the German-writing intellectual tradition as a whole. Clearly, the ways in which the discipline was distorted and mobilized for reactionary political ends have long been recognized and articulated both in its Volkskunde variant (Emmerich 1968; Gerndt 1987; Lixfeld 1994) and in its Völkerkunde variant (Fischer 1990; Linimayr 1994; Dostal 1994; Hauschild 1995; Streck 2000; Schafft 2004). Deeply implicated in racial theories, German Volkskunde is often taken as an example of the total corruption, perversion, and "nazification" of a discipline (Dow / Lixfeld 1994), while its practitioners had compromised their scientific integrity to provide scientific support to the fascist ideology and the nationalist and racist policies of the Third Reich. In grave disrepute after 1945, the discipline was obliged to submit itself to a new beginning, which encompassed changes not only in personnel and institutions but also in theoretical orientations.

However, while Volkskunde as a whole was obliged to break with its own traditions, these studies in East Germany remained still preoccupied with approaching Volkskultur in the same essentialist terms. The communist holders of the new totalitarian and autocratic power were initially hostile to this seemingly petit-bourgeois discipline, with its curious obsession with the preindustrial peasantry, supposed repository of the unsullied essence of the nation. Before long, however, they seem to have concluded that such research was harmless enough, and perhaps even useful in legitimizing their own programme. Actually, during the early decades of socialism, the Volkskunde tradition had another, seemingly quite different tradition grafted on to it. Under the label of Ethnographie, they emulated Soviet etnografiya and followed the logic of the latter's development and separation from folkloristika (cf. Hann / Sarkany / Skalnik 2005).

It is possible that an earlier stage of this elaboration is rooted in a common ground to both Russian and German anthropological traditions, as an intimate acquaintance with descriptive and synthesizing reports of Siberia may have already contributed to the theoretical conceptualization of a German equivalent term of Ethnographie in Göttingen since the 1770 s, which was originally elaborated as synonymous with Völkerkunde, in analogy to geography and its German counterpart Erdkunde (Gingrich 2005: $70 \mathrm{f}$ ). However, it is more for specific historical reasons that have more to do with the Soviet influence in Eastern Europe, rather than with nineteenth-century developments that saw the field of a descriptive ethnography become opposed to the theoretical field of ethnology, that the emulations of Soviet etnografyia 
in Eastern Europe are often rendered in English with a homographic term such as "ethnography", which is often confused with the allophonic term of the method of "ethnography" in anthropology.

In particular, an emblematic Soviet scholar named Sergey Tokarev was posted since 1951 to East Germany to teach for some years at Humboldt University in East Berlin and Karl Marx University in Leipzig. Altogether with a few re-emigrants and party ideologists, he greatly influenced the radical kind of transformation and promotion of a dogmatically Marxist Ethnographie out of Völkerkunde and Volkskunde under communist rule in East Germany. Some leading figures of East German Ethnographie now tend to play down the intensity of Soviet links in general and Tokarev's contribution in particular (e.g. Jacobeit 2005; Treide 2005). However, for most of Tokarev's German students the task was the creative application of theory to the particular social and political situation of East Germany (see Noack / Krause 2005: 30). According to an internal report in the Archives of Humboldt University in Berlin, he must have provided "essential advice for the development of a Marxist Ethnographie," while his lectures, which served as an important reference for generations of students, were designed exclusively to promote the "Sovietization" of people's culture studies (Heyden 2005: 306).

Whether the German Volkskunde tradition and the Soviet etnografiya tradition share common intellectual origins and scholarly trajectories, or the latter was grafted upon the former in other East European countries under the direct influence of East German scholars remains open to discussion. ${ }^{6}$ Yet, a homology between German Volkskunde and Soviet etnografiya can be posited on the ground of their particular political and geopolitical frameworks in which they functioned. Some incisive analyses show how the distorted political ends of Volkskunde were deliberately mobilized and re-launched after 1945 in the East German Zone of Soviet administration later to become the German Democratic Republic (Scholze 2001).

East German Volkskunde conceived culture as a core characteristic of a deliberately ethnicized concept of folk, which merged into that of people and nation, paralleling the concept of "ethnos" in Soviet etnografiya (Bromley / Kozlov 1989). While the category of "people" (Volk) slipped easily from connotations of "traditional" and "archaic" into a political equation of "people" with "nation", it was increasingly associated with an additional socio-class understanding of the "people" (Volk) leading to a specific concept of people's culture as the socialist culture of "working people", best elaborated in the socio-class category of "demos", which in East German Volkskunde was distinguished from the more general ethnocultural category of "ethnos" (Noack / Krause 2005: 42). Such a refinement in East Germany might have been useful to avoid the thorny question of East German nation in the context of a divided Germany (Mohrmann 2005: 198).

Yet, the recognition and accentuation of people's culture as the socialist culture of "working people", namely the oppressed people, who according to Marxist ideology are uncompromisingly opposed to exploitative classes, was also an important consequence of Leninist

6 In Albania during this period, for instance, contacts with Soviet scholars were non-existent and no known Albanian practitioner of people's culture studies was trained in the Soviet Union (Doja 2015). The only joint research project with colleagues from another "brother" country of the socialist camp was one in collaboration with East German scholars investigating folk music in Albania. Nevertheless, when I joined the Institute of People's Culture in 1985 as a young researcher, even though Soviet intellectual influences were definitely outdated, I was told by my older colleagues that one of the best handbooks of people's culture studies that had helped them to complete their training was written by a Soviet scholar named Sergey Tokarev. I was also advised to use him, as a translation of his works into Albanian could be found in the Archives of Institute of People's Culture in Tirana. 
theory of two exclusively differentiated national cultures in class societies. In East Germany researchers were now in charge of a broader perspective on the study of socialist transformations and new ways of life, following the Stalinist concept of building a new Volkskultur to be "national in form and socialist in content". As in other East European countries, East German Ethnographie was only too pleased to participate in advancing notions of authenticity and superiority of the socialist people's culture. The internal cultural regimentation following the exclusionist communist project and propaganda provided a firm base to establish a presumed common code of socialist morality, thus transforming cultural and historical traditions into instruments for justifying and magnifying the "original", "authentic" and "immutable" people's foundations of the authoritarian regime. In turn, the emulation of these studies must have mattered in an extreme, sometimes devastating way for many people throughout the Socialist Europe, by giving legitimacy and laying "theoretical foundations" to the socialist characterization of some people's life and culture as "backward" and therefore "alien" and "disintegrative", which justified the policies of class repression, expulsion and resettlement. Ultimately, this must have laid the ground for the exoticization and racial hierarchization of these people, especially in the margins of Europe.

\section{Albanian research after Socialism}

After the Second World War, the early twentieth-century image of the Albanians was frozen until the end of the century when the country opened again to foreign travelers, like the other East European countries that were rediscovered as "new exotic lands" in the aftermath of the demise of Socialism (Skalnik 2002). Interestingly, the North Albanian mountain territories were exploited from the early to the late twentieth century in very similar ways, open to discoverers and adventurers (Kaser 2002). Reports of a traditional social structure based on kinship, together with the blood-feud and the archaic customary and legal institutions, have aroused the enthusiasm of many Western scholars and journalists, not necessarily limited to a German-writing tradition. It seems that a pervasive continuity in Albanian studies, as elsewhere, is that fiction played an enduring role, taking literally many issues played out in nonacademic texts. Particularly, a rewriting of customary laws seemed to be the translation in Western languages of the famous Albanian novelist Ismail Kadare's Broken April in the 1990 s. $^{7}$ Afterwards, many continue to flock to the highlands of northern Albania in search of what they imagine, again, to be the distilled essence of the mountain spirit, a barbarous and splendid anachronism embodied in a sort of primitive and fearless mountain people living according to an ancient code of honour enforced by "tribal" law on the margins of modern Europe.

Marriage codes, blood feuds, religious beliefs, hospitality, as well as certain peculiar customs such as the "sworn virgins", those women who allegedly still continue to obtain male status by pledging eternal virginity (Young 2000), or the distorted use of "biography" that is said to have been specifically exemplified during Socialism in Albania (Rapper 2006), are put under the spotlight and conventionally described by contemporary foreign writers. Their common approach is simply meant to single out exoticized patterns of traditional social structures, not unlike what Edmund Leach once unforgettably denounced as "the butterfly collecting" of older forms of anthropology (Leach 1961: 2). They still address readers' curiosity with a colorful touch and amusing reflections, peppered with adventure and mishap, discovery and unexpected encounters. Incidentally, they may cross Albanian "savage" and "accursed" mountain wreath on horseback, in the footsteps of Lord Byron, Edward Lear and Edith Durham, portraying the "Land of Eagles" or Europe's forgotten country (HanburyTenison [2009]2013) as a ruthless and archaic society completely untouched by the twenty-

7 1982: Avril brisé, Paris; 1990: Broken April, New York / NY; 2001: Der zerrissene April, Zürich. 
first century, an unconventional destination, a mysterious and eccentric picture from another era, a land of tribal warriors and fairy tales.

In the hard times of post-communist turbulence during the 1990 s many Western commentators are easily willing to believe that Albanians still live by the strict laws of the Kanun, fuelling again the pictures of a Balkan otherness and bolstering the impression that despite all efforts this part of the world is not able to Europeanize itself. While some try to address the historical and political complexity of related practice and discourse (e.g. Resta 2002; Voell 2004), showing the "strategic subversion of stereotypes" (Schwandner-Sievers 2008), others do not hesitate to mount virulent rhetorical attacks of denigration and vilification on the ground of a presumed "irrationality" of a "culture-bounded" people (e.g. Carver 1998; Krasztev 2002). Many publications over the recent decades have been using overlapping elements of Balkanization and Orientalization over and over again, mixing frozen images up with new elements, like the one about thousands of bunkers that were built in the communist times (Kaser 2002), or the standard stories of the "land of the Mercedes" owners in Europe (Clayer 2003).

This kind of writing seems to be a pure construction and an act of ethnocentrism. Prone to what Johannes Fabian calls "allochronism" (Fabian [1983]2002), the writers created an allochronic discourse according to which the Albanian "Other" never occupies the same historical time as the Western observer. They created a certain stereotype, not only of "a land of the living past" (Durham [1909]1994: 1), but also a mixture of exoticism and "Balkanism" (Todorova 1997), partaking in the logic of many "nesting orientalisms" (Bakic-Hayden 1995), regarding a "terra incognita" (Pandolfi 2005) on the "margins of Europe" (Herzfeld 1987), which promoted an image of Albania and the Albanians that approximated almost any people in the world, but never Europeans. The discussion on this topic, opened by Edward Said's Orientalism (1978), has traced the West-East conceptualization of cultural differences to its intellectual roots of eighteenth-century Enlightenment (Wolff 1994). Seriously, the continued strength of such exoticism in Western scholarship is shocking. Already in the 1950 s Claude Lévi-Strauss in his Tristes Tropiques ([1955]1973) had bitterly deplored similar stances in anthropology. To borrow his terms, this literature on Albania would represent another instance of the same mistake of a whole profession or a whole civilization in believing that men are not always men, that some are more deserving of interest and attention only because in the midst of Europe they seem to astonish us by the apparent strangeness of their customs.

Many Albanian research produced in the modern tradition of German-writing and Western scholarship may show a great concern for ethnographic approach and historical sourcecriticism or a high level of academic sophistication. Yet, the aspects of what is referred to as Western tradition pertain to an entity characterized by inner mechanisms of exclusion and hierarchies. Actually, the racial hierarchy and developmental logic of Western culture has been the foundation of power relations in the last two centuries. In this context, the public legitimacy of current scholarship requires a more serious engagement with the nationalcommunist debates on exclusivism. Undoubtedly, it is still important to clearly show how the eighteenth-century Romantic legacy became corrupted in a variety of cultural and political ways by twentieth-century professionals who may have legitimated nationalist ideologies and their communist socio-class variations. It is equally important, however, to equally engage with the post-colonial and post-socialist arguments on imperialism and with the ethnocentric and authoritarian discourses on the global politics of knowledge and truth.

Whether or not Europäische Ethnologie, which has displaced Ethnographie at Humboldt University in Berlin, is derived to a large extent from long-established historicist trends in Volkskunde and the disciplinary vision developed during the socialist era (see Noack / 
Krause 2005: 46; Jacobeit 2005: 183) is open to discussion. At any case, it seems that many contemporary Western studies deemed to be value-free and more sophisticated may often show similar serious problems of either methodological and theoretical or political and ideological implications, which are by no means limited to a German-writing tradition. The contexts of the geopolitical position of German-speaking countries towards Southeast Europe after the political turns of the $1990 \mathrm{~s}$ in East Europe and their respective activities of scientific research are now determined by a neoliberal context dominated by programs of institutional establishment and the installation of a new public space.

Even before the end of the Communist regimes in East Europe, in the mid-1980 s, the Austrian politician Erhard Busek addressed historical connections between Vienna and Southeast Europe. This happened within a general, liberal-conservative discourse on Projekt Mitteleuropa, intended to help strengthen various local dissident persons and groups in their endeavour to fight and topple their respective Communist regimes. Such endeavours were supposed to secure Austria, as the core of the former Habsburg Empire, a convenient position as intermediary in the political rollback in East Central Europe (Busek / Brix 1986). About a decade later, the Special Coordinator of the Stability Pact for South-Eastern Europe launched by the Western states in the aftermath of the NATO intervention in Southeast Europe, in his subsequent book on Österreich und der Balkan, pleads for specifically refreshing the old links (Busek 1999).

\section{Current Ostpolitik of knowledge and truth}

During the recent decades, a complex network of international political strategies has been set up in most East European countries with the aim of teaching "governance" in conformity with Western European standards of democracy and market economy. Members of the Austrian political and economic elites also advocated various internationally accorded political, economic and ultimately military interventions in Southeast Europe. By doing so, new forms of globally organized post-colonial and post-socialist topographies of power and expertise are "disguised by discourses of Europeanization, marketization and democratization typical of the globalist transitional rhetoric", as aptly qualified by one anonymous reviewer. As I showed elsewhere in more detail especially in relation to Albania and Kosova (Doja 2001), located within new transnational regimes, humanitarian organizations, international institutions, and specific segments of local elites, they are transferred into the local political field of power and they operate in networks that spread in the private and public spheres. They are canonized as models of governance that legitimize the right of interference and intervention, the rhetoric of institution building, and a Western, neo-liberal, forced democratization of the Southeast "margins" of Europe. The power they wield is real, superimposed as it is onto bureaucratic procedures and intergovernmental negotiations, transforming itself into a new form of transnational domination. The current collaboration of German, Austrian and Swiss scholars with Albanian intellectuals can also be usefully framed within this neoliberal context where the EU European presence frames the supra-colonial conditions of knowledge production that determine the perception and the regime of these "trouble spots" on the margins of Europe.

Among other things, Southeast European studies invoke the diverse cultural attractions of a seemingly forgotten region that now, after the end of Communism and the ensuing Yugoslav Wars, has got rid of various ideological obscurations. Such a discourse reiteratively reinstates the region as a buffer zone between the West and the Rest, associated with a distant past and "exotic" charm as with various "un-European" and not "really modern" elements, while they associate themselves with civilizational progress and a metropolitan center. Much the same as in the imperial past, they see the region as a target area of specific 
economic and financial interests of a part of the Austrian elites to establish themselves as regional players (Promitzer 2012). Interestingly, such activities are propagated, legitimized and embedded within the framework of a common history, namely by underscoring the links of the Habsburg Empire to Southeast Europe before the First World War, more specifically the Austrian impact on the independence of Albania.

In any case, local intellectual and cultural elites in both German-speaking countries and Southeast Europe, including Albania, are interested in Southeast European "culture" and German or Austrian "aid" in a way that prevents them to develop a critical understanding of the supra-colonial impact (Pandolfi 2000) of the German and Austrian activism in Southeast Europe. ${ }^{8}$ Apparently, this relationship is articulated in the iconic guise of a national culture aggressively fashioned to suit Western values promoted by German and Austrian models. With a typical self-colonizing attitude (Kiossev 2011), native scholars educated or established within German academia (e.g. Martin Camaj or Bardhyl Demiraj, the first and the current chair holders of Albanologie at Ludwig-Maximilian University in Munich) willingly perpetuate the folkloric essentialism of historicist philology. As a result of this crypto-colonial situation (Herzfeld 2002), Albanians are placed on high cultural pedestals but effectively isolated from other, more brutally material and authoritative forms of power, which ultimately exclude them from access to the globally dominant advantages of modernity.

In addition, much the same as in the second half of nineteenth century and at the beginning of twentieth century when Albanologie was founded almost exclusively by a generation of German-speaking writers, it seems that many contemporary German-writing scholars are now taking a new lead in a joint effort to repair what they believe are the culturalist mistakes of previous studies or the nationalist presumptions of local scholars. Interestingly, however, in most cases they take over in their own account the dichotomous way of thinking that is supposed to stem from more traditional Albanian social structures but emphasized during socialism, according to which it is not uncommon for scholars to be classified under the categories of "natives" and "foreigners" or "friends" and "foes".

Western representations of the "other" are normally criticized by anthropologists, but these hegemonic classifications and a kind of arrogant "exoticizing" and "patronizing" continue even today with some scholars who live in the West and work in the post-socialist East. Frankly, while long-lasting paradigm shifts and actual practices triggered by the transnationalization of scholarship are ignored, a hierarchical order of scholars replicates Cold War stereotypes and supra-colonial patterns of knowledge production, as is shown in similar Central East European contexts (Skalnik 2002; Buchowski 2012). Here we may also consider the lasting effects of a similarly "exoticizing" and "patronizing" Mediterranean ethnology worked out mainly by Western anthropologists, who are heavily criticized for ignoring local scholars, especially in the case of Greece (Gefou-Madianou 1993). One may also be reminded of British anthropologists who worked outside Europe and who belatedly realized that they were or were seen as part and parcel of colonialism and imperialism (Asad 1973; Stocking 1991). Still, like their Central and East European counterparts, proficient Albanian-born scholars are often disregarded simply because it seems presumptuous from scholars of some localized and otherized stock to make any actual point in the reserved "in-

8 This can be shown, for example, by the organization and the proceedings of a spate of joint conferences celebrating the Austrian impact in Albanian scholarship and state-building, in May 2012 in Shkodra and in October 2012 in Tirana, or more specifically focused on the celebration of German Albanologie as a model for the contemporary development of Albanian scholarship, in November 2010 and then again in October 2013 in Tirana. Not surprisingly, the critical approach of a few young Austrian scholars is blindly ignored, even though by chance their papers may be given at the very same conferences (e.g. Gostentschnigg, in: Marashi / Rakipi 2013: 39ff). 
ternational theories", as if they could at best nothing but add exegeses and footnotes to "foreign" theorizing.

A case in point is a Vienna meeting sponsored by the Austrian Academy of Sciences where mainly German and Austrian scholars gathered together with only "scholars who do not originate themselves from the region" (Schmitt / Frantz 2009). Their goal was "to create a solid basis for a future comprehensive discussion with Albanian scholars". It was not clear whatsoever why "a look from the outside is deliberately chosen" that should "exclude Albanian scholars" from such meetings. Actually, it was "to be hoped that such a chosen look from the outside would have the advantage of avoiding the emotional debate and the significant politicization of history and culture in current Albanian studies". But it was not clear why the exclusive fact of a German stock in the pedigree of scholars, for instance a Schwyzer Tütschman or Wiener Stutzer (Swiss countryman or Viennese coxcomb), should be better situated than other scholars to "contribute to professional and fact-oriented scientific discussions" (Schmitt / Frantz 2009: 9).

When it comes to scholars who are perhaps difficult to qualify as either "native" or "foreign" because of their being both Albanian-born and proficient in Western academia, it seems that their proportion of Albanian stock might induce some of the German-writing associates to indulge in misinterpretation of arguments behind a cloudy "international theory discourse" to which Albanian scholars must be taught (e.g. Schwandner-Sievers, in: Schmitt / Frantz 2009: 173ff). ${ }^{9}$ Or else, they may even deliberately close their eyes to certain contributions even though this must have been quite relevant to the topic at hand (e.g. Clayer 2009: 107ff). ${ }^{10}$ Not incidentally, however, for lack of a better engagement with scholarly debates, many of them only rely on whoever paranoiac and hanger-on pseudo-scholars in Albania, who are nothing but the by-product of "the social life of projects" and "the western models of civil society" imported to Albania (Sampson 1996). The greatest merit of some of them (e.g. Ardian Klosi and Fatos Lubonja) is their notorious affiliation to the former

9 Stephanie Schwandner-Sievers seems not to have been yet liberated from the ethnocentric bias of considering that some paths can be only beaten by some scholars rather than others, or be the appanage of Western stock. In her rush to display her cherished "international" slant on the history of ideas and theories, oddly enough, she can only play the old "lit-crit" "post-crit" fiddle of deconstructionism. Eventually, she ends up by failing to correctly understand the current theoretical and epistemological debates in general anthropology, in which some other scholars may have been engaged. (For more details on the extent to which current interactionalist and constructivist approach is used for understanding the instrumentality of religious shifting in the historical reconstruction of identities in multi-religious Albania, see Doja 2000. For more details on the poststructuralist debate, see Doja 2006 b, 2006 c, 2007; on Lévi-Strauss's actual theoretical and epistemological contribution to general knowledge, see Doja 2005 b, 2006 a, 2008 a; on the relatedly debated cultural ideologies of ethnocentrism, nationalism, essentialism and fundamentalism, or pluralism, neo-liberalism, post-modernism, relativism, humanism and universalism, see Doja 2008 b, 2010 a, 2013 a).

10 Nathalie Clayer is an unsophisticated writer. Her only merit, beyond her putative German stock, is perhaps her partnership with some notorious brand of Serbian ultra-nationalist scholarship, which might have provided her with some dubious familiarity with Balkan issues, including Albania. Actually, her claims are stubborn in showing the exclusive Muslim "Other" in the Balkans, like the exclusive "birth of a nation of Muslim majority in Europe" (Clayer 2007). Not only are these claims based on a deliberate use of selective data and an outright exaggerated point of her own, but they also essentialize and reify the otherization of some given nation, and ultimately work for the ideological purpose of civilizational drifts within the Balkans and within Europe itself. (For more details on the instrumentality of religious shifting in the historical reconstruction of identities in multi-religious Albania, see Doja 2000; on the historical development of Bektashism and the political instrumentality of its religious structure within a general ideological cultural system, see Doja 2006 d, 2006 e, $2006 \mathrm{f}$; on the supposed elective affinities of nineteenth-century Albanian nationalism to religion and specifically to Bektashism, see Doja 2013 b; Abazi / Doja 2013). 
regime. ${ }^{11}$ Some others are better known in vernacular Albanian as dumbabist, with reference to the 1914 rural rebellion that shortly after Albanian independence claimed the return to "Father Sultan" of the Ottoman Empire, but which can be freely extended to the former as to all charlatans in need of whichever patronal support in post-socialist post-colonial Albania. Their misuse and abuse of out-of-context theoretical concepts and their seemingly nonconformist media stunts and diatribes are taken at face value, sponsored as a rule by Western public funding, simply because certain Western individual scholars may often take over from them in the mass media and Internet forums to legitimize their own prejudiced positions and buttress their own academic careers at home.

Regarding the nationalist and essentialist presumptions of local scholars, the methods and results of Albanian research related to the issue of Albanian ethnogenesis have already been subjected to a detailed critique by German scholars (Tönnes 1980). However, preoccupied as they are with identifying the "correct" Albanian old language and history, not unlike previous research, contemporary German-speaking writers still end up with a similar search for origins (e.g. Schramm [1994]1999; Matzinger 2009), which cannot bring by any means the irrefutable evidence necessary to make justice to supporters of one or the opposite thesis at hand. Whether hazy hypotheses or revealed truth, they may start the discussion anew, but with old and new arguments that are already condemned for their use and abuse against Albanian and pro Slavic nationalistic purposes (Gostentschnigg 2006). Ultimately, such endless search for origins seems unable to move away from the useless obsession with the problem of ethnogenesis. While they notoriously introduce something as a protohistoric concept of Albanians being descended from "Proto-Albanians" (Matzinger 2009), just as more or less man descended from monkey, unfortunately they remain far away from historically approaching dynamic and political processes within actual groups and communities.

More serious, however, is the explanatory framework and the way in which the intricacies and motivations behind much of Albanian history are dealt. A case in point is a book against the autochthony and Illyrian character of the Albanians, trying to prove their immigration from the Central Balkans into their current Western settlements probably at the beginning of ninth century (Schramm 1999). The new hypotheses are characterized by a careful historical evaluation of philological sources, especially the borrowed toponyms shedding light on the periods of Late Antiquity and early Middle Ages for which there are only a few sources. Yet, as among the young generation of German-writing scholars also indicate, the systematic use of qualifications such as "barbaric language" or "barbarous tribes" that permeate the whole book, meaning everything non-Roman, non-Greek or non-Slavic, seem inconsiderate for a historian of the end of twentieth century and may at least make any reader feel uncomfortable. Actually, as stated by (Gostentschnigg 2006: 59), after a thorough reading of this certainly interesting but in many parts almost adventurous book, one is tempted to return to the author the condescending criticism of emotional approach that he arrogantly makes of local scholars.

Contemporary German-speaking writers may be eager to claim a "neutral approach to the origin of Albanians and Albanian language with the help of a historical linguistics that is only committed to linguistic data and independent of any political motivation" (Matzinger 2009: 35). They are much at pains, however, to stress "the importance that from linguistic findings no territorial claims whatsoever must be derived in the present". They are actually

11 They silence the fact that they have been part and parcel of the system that built the very dictatorship of the communist regime to which some among them may have succumbed after having benefited the most, just as they continue to do from today's civil society. They seem not liberated from their persecution complex of hatred and contempt, while more than anything else they continue to grieve for a power lost. 
anxious to stress that "historical linguistics interprets with its traditional methodology each language data in a neutral way and regardless of national political sensitivities", or else "the politicization of these findings from both ethical and scientific points of view is in all respects inappropriate and inadmissible" (Matzinger 2009: 35). More than anything else, however, such a discourse sounds likely to reproduce the demagogic authoritarian discourse that was practiced during national-socialism and communism by both political leaders and their acolyte scholars.

Similarly, in spite of the author's claim to pay more attention to a Southeast Europeanwide dimension that must not incorporate modern ethno-national schemes, a recent monograph on Skanderbeg (Schmitt 2009) does the best to show exactly how large Skanderbeg's non-Albanian stock was, just as not incidentally the same author and his associates consider still important the ethnic stock of scholarship (Schmitt / Frantz 2009). Surely, the author is not so much to blame because he dismisses and demystifies the Albanian national character of the fifteenth-century hero as many Albanians believe. ${ }^{12}$ On the contrary, they should be proud of such a rendering of their national hero as the "New Great Alexander of the Balkans". ${ }^{13}$ But this should not be a compliment for a scholarly work. More seriously, indeed, the explanatory framework of the author seems to be flawed in his misreading of some forged documents, when the author takes the report of Italian diplomats as if these were the actual words of Skanderbeg's envoy to Pope Nicholas V in January 1454. Actually, in a rather typical style of diplomatic reporting, the diplomats clearly mix the facts with their own interpretation of the facts, and such a misreading must be either deliberate or otherwise inconceivable at the hand of a 21 st-century historian. ${ }^{14}$ He nevertheless managed to project common modern Orientalizing and Balkanizing stereotypes of the purported Albanian tribal laws, blood feuds and the like into his picturing of a fifteenth-century character, not unlike the old generation of Austrian and German writers, typically aiming at sensational discoveries to acquire artificial prestige in network ratings. If this is the case, he would better try Skanderbeg for a homosexual, as this might have been much hipper nowadays, might not it?

12 The book is published in German only after one full year of media coverage was given to the Albanian translation sponsored by the Swiss Agency for Development and Cooperation, which is responsible for Switzerland's overall international coordination of development activities and cooperation with Eastern Europe. In so doing, the Swiss Embassy in Albania is denounced for sponsoring the humiliation of Albanian national symbols, and hence not only violating international law governing diplomatic activity, but also committing a criminal offense under the provisions of the Albanian Criminal Code. At the same time, the German Embassy in Albania is also denounced for sponsoring a documentary film as an electoral spot under covert German and Austrian funding, where hanger-on pseudo-intellectuals pushed as "the most prominent enlightened intellectuals of the country" are converted into Albanian national symbols. Whether such accusations are grounded or not may be open to discussion, but they compelled the major Swiss newspaper Neue Zürcher Zeitung to plead the cases before German, Austrian and Swiss public opinions in a debate published on 18 March 2009.

13 For 25 years the Albanians had fought under Skanderbeg's leadership (1443-1468) to resist Ottoman annexation, for which he earned the papal commendation of Athleta Christis by Pope Callixtus III (1455-1458) and was even expected by Pope Pius II (1458-1464) to lead the attempted crusade against the Ottomans in 1464.

14 "In these circumstances came Skanderbeg's envoy to the Pope and said that because of personal hatred against the Turk" (Schmitt 2009: 57). Instead, the diplomats write: "Qua è gionto uno cavaliere ambasatore [...] di Signor Xanderbech [...] e richiede al Papa che lo faza forte de X.M homini e lui li volle metre tuti li suoy subditi in maior numero asay per andare contra el Turcho; e questo non per fede, perchè ancora lui è infidele, ma per hodio privato ha cum el Turcho, lo quale Turcho fece morire lo padre de quel tal Signore e questo tal Signore ha facto morire uno fratello del Turcho" (Fac-simile reproduced in the appendix of the book). Obviously, it is rather naïve to believe that something like the last sentence could have been said by Skanderbeg's envoy to the Pope. 
A related problem may be a definite moral-ideological position and orientation on Albanian rustic patriarchy, which is very much in line with the Western academic "good citizens" for whom "patriarchy" is the ideological bogey-man just as communism and nationalism are for the neo-liberal free-marketers and multiethnics. In this context, the study of family structures is of relevant importance, though less developed in anthropology than history, where a number of historical works have widely explored western European family and household structures or the transmission of familial property through generations in its consequences on social structure and economic development. They also address questions of kinship structures, the composition of traditional complex families and the principles of household formation in Southeastern Europe. In particular, contemporary German and Austrian historical studies have developed in the recent decades a strong historical research specialization, especially at the universities in Vienna and Graz, and produced a series of publications on the Albanian and wider Southeast European kinship structures or family systems in European comparative perspective (see Kaser / Gruber / Pichler 2003).

Unfortunately, some of them still reproduce old patterns of cultural particularism and cultural determinism as they seem to not have been totally liberated from the old culturalist legacy of the Kulturhistorische tradition. Well versed as they are in using the empirical evidence from a wide range of sources, as I showed elsewhere in more detail (Doja 2010 b), they endlessly try to divide and typify cultural areas in Europe and in Southeast Europe, reminiscent of the anthropo-geographical Kulturkreislehre of the old Vienna school. ${ }^{15}$ These typologies proceed along the lines of purely demographic criteria confined to the evaluation of quantitative data. In doing so, they typically bring back the common approach of "butterfly collecting" that was once unforgettably denounced by Edmund Leach for older forms of anthropology (Leach 1961: 2). Whatever may be the criteria of simplification used - taken as a rule from characteristics that can be found in sources such as birth, marriage and death registers or census lists, any of such typologies is stereotypically meant to single out exoticized patterns of traditional social structures.

Arguably, this kind of evidence becomes flawed when it is forwarded in support of a position that assumes, for instance, a so-called "Balkan family pattern", which is supposed to be characterized by equal partible inheritance and a multiple-generational household cycle rather than an individual life-cycle. In addition, while in a northern variant scarcity of land and high population density seem to be the decisive factors, the southern variant turns out to be characterized exclusively by a distinctive patriarchal cultural background, where institutional factors and ideological elaborations have got muddled up in what some Austrian scholar blatantly reifies as "Balkan patriarchy" (Kaser 1992, 2008). Not surprisingly therefore, all this becomes good to characterize these peoples as usual, that is, caught up into their agnatic dyadic relationships or their supposed "tribal" organization and "tribal" laws, including not only complex family structures and especially many children, but also predatory warfare, blood feuds, honour killings, birth customs and ancestor worship, cradle betrothal and bride purchase, and other "savage" customs of the like.

Similarly, the cultural myths and ideologies associated with patrilineality are conflated with the actual practices of patriarchy and it is too easily assumed that the patriarchal language and discourses that symbolically support patrilineality result uniformly in outcomes

15 As I was giving a paper on a related topic at a conference on the rise of anthropology in the Southeast "margins of Europe" during socialism, organized in March 2011 by the Max Planck Institute for Social Anthropology in Halle/Saale (Germany), in his discussion following my presentation, Austrian anthropologist Andre Gingrich confirmed my contention by telling us his shock at assessing a similar project submitted for funding to the Austrian Academy of Sciences. He didn't disclose the topic or the name of the promoter. 
and practices that are simply reified as patriarchal (e.g. Kaser 2008). As a result, a purely ideological dimension is commonly obscured. On the one hand, a more careful reading and systematic critical analysis of demographic data, historical sources and ethnographic evidence carried out elsewhere (Doja 2010 b) clearly shows that the Albanian family has been confronted for a long time with particularly low fertility rates and with a relatively high average age at marriage for women. On the other hand, a more experiential understanding of ethnographic evidence (Doja 2013 a) makes us aware that social behaviour related to sex selection at birth or ways of expressing labour pain at childbirth (Doja 2005 a) can be another indirect indication of women's agency to reassert their role in reproduction and work around traditionalist frameworks of patriarchal ideology. Actually, both Albanian women and men are more likely to prefer sons but both are also likely to try for a daughter, especially after a son, or they may even be likely to say that their female child was preferred. This is true despite their apparent overwhelming preference for a son, despite women's relative lack of autonomy in reproductive decisions, despite the fact that women rarely report challenging their husband's decisions, and despite the fact that they rarely report agreeing with their situation in the family and society. In turn, the cultural pressure aimed at limiting Albanian women to their childbearing function, more than anything else allows us to account for the structural, historical and political conditions in which social behaviour takes place. The myth of many children within the so-called clan structures of the supposed patriarchal Albanian family is commonly constructed and conveyed in academic writings, the media and stereotyped opinions. I showed, however, how the ideological construction of this myth can be invalidated, if we take what is put forward as empirical evidence to be nothing more than a strong cultural activism where women are subjugated to the reproduction of the social group.

Seriously, after the "writing culture" debate (Clifford / Marcus 1986) and the declaration of war against "reification" and "essentialism", we have become even less able to address that dimension of human life on which anthropologists used to claim some expertise, namely the normative, non-rational, yet intrinsically meaningful aspect of social life we still label "culture". In our eagerness to deconstruct whatever entities were formerly considered to be "out there" and to highlight process and agency over structure and culture, we have contributed to making it intellectually and politically contentious to talk intelligently about differences that very tangibly affect people's lives. To account for the structural, historical and political conditions in which social behaviour takes place is not to offer a blanket condemnation of a given culture. Acknowledging the cultural dimensions of human acts and motives need not imply a simplistic understanding of "culture" that reduces all members of a community to social beings who "have a culture" and are "culturally determined" in their individual experiences and their personal aspirations, nor that they are pre-programmed to react in the same manner.

\section{Conclusion}

The specific essentializing discourses and the patronizing attitudes of Western scholarship, of which the imperial aspiration of German-writing Albanologie can be taken as an illustrative example, certainly appears unusual and difficult to grasp, if one schematically employs traditional categories developed in current scholarship dealing with questions of Albanian "people's culture". In turn, an articulate analysis of the main intellectual traditions and their impact, linked to a careful examination of the historical contextualization in ideological perspective, is likely to produce a more sophisticated understanding of the German Kulturpolitik of Albanologie. While analyzing the historical, cultural, and political terrain in which certain influential ideas and practices emerged, the aim of this article was to frame the argument in such a way as to focus on a critical reassessment of different strands of scholarship and to take into account the close association of the development of Albanian research in 
German-speaking countries with the imperial colonial, national communist and post-socialist post-colonial context and ideology.

In methodological terms, I tried to engage with a comparative analysis of ideas and practices rather than with a search for positive literal proof. The presentist approach and critical interest advocated here might not be exhaustive, and certainly a number of questions that remain open will require complementary historicist and historiographic efforts. My presentist and critical approach definitely is positioned and selective. However, if this article has managed to provoke at the very least a non-stereotyped discussion throughout a set of reflections on German-writing scholarship on Albania and the Albanians, it merely offers itself as one among several possible alternatives. I hope it will encourage further debate, deeper enquiries, and thorough reflection, which can suggest different explanations. Even though it might perhaps justifiably attract attention to criticism, it may hopefully stimulate and enrich a debate that could much contribute to the already critical research on historical and current Europeanization. Ultimately, while the difficulty of simultaneously taking into account distinct strands of academic traditions is clearly realized, I believe the attempt to articulate them in relation to one another may lead to a fascinating intellectual problem. The conceptual aspects of this situation not only show how to deal with an extant social structural problem of knowledge production but may also have important theoretical and methodological implications beyond those of the specific problems addressed in this article.

\section{References}

Abazi, Enika / Albert Doja (2013): Further considerations on the politics of religious discourse: Naim Frashëri and his Pantheism in the course of nineteenth-century Albanian nationalism, in: Middle Eastern Studies 49 / 6, S. 859-879.

Asad, Talal (ed.) (1973): Anthropology and the colonial encounter, London.

Bakic-Hayden, Milica (1995): Nesting Orientalisms: The case of Former Yugoslavia, in: Slavic Review 54 / 4, S. 917-931.

Bausinger, Herman ([1971]1993): Volkskunde ou l'ethnologie allemande: de la recherche sur l'antiquité à l'analyse culturelle, Paris [Orig. Volkskunde: von der Altertumsforschung zur Kulturanalyse, Darmstadt].

Bromley, Yulian / Viktor Kozlov (1989): The theory of ethnos and ethnic processes in Soviet social science, in: Comparative Studies in Society and History 31 / 3, S. 425-438.

Buchowski, Michal (2012): Intricate relations between Western anthropologists and Eastern ethnologists, in: Focaal: Journal of Global and Historical Anthropology 63 / 1, S. 20-38.

Busek, Erhard (1999): Österreich und der Balkan: vom Umgang mit dem Pulverfass Europas, Wien.

Busek, Erhard / Emil Brix (1986): Projekt Mitteleuropa, Wien.

Carver, Robert (1998): The Accursed Mountains: Journeys in Albania, London.

Clayer, Nathalie (2003): God in the Land of the Mercedes: The religious communities in Albania since 1990, in: Österreichische Osthefte 17, S. 277-314.

Clayer, Nathalie (2007): Aux origines du nationalisme albanais: la naissance d'une nation majoritairement musulmane en Europe, Paris.

Clayer, Nathalie (2009): Religion, Nationsbildung und Gesellschaft, in: Schmitt / Frantz 2009, S. 107-118.

Clifford, James / George E. Marcus (eds) (1986): Writing culture: the poetics and politics of ethnography, Berkeley / CA.

Deusch, Engelbert (2009): Das k.(u.)k. Kultusprotektorat im albanischen Siedlungsgebiet in seinem kulturellen, politischen und wirtschaftlichen Umfeld, Wien. 
Doja, Albert (2000): The politics of religion in the reconstruction of identities: the Albanian situation, in: Critique of Anthropology 20 / 4, S. 421-438.

Doja, Albert (2001): Démocratie et stabilité dans le Sud-Est Européen: facteurs humains, culturels et sociaux, in: Les Temps Modernes 56 / 615-616, S. 147-166.

Doja, Albert (2005 a): Rethinking the Couvade, in: Anthropological Quarterly 78 / 4, S. 919-951.

Doja, Albert (2005 b): The advent of heroic anthropology in the history of ideas, in: Journal of the History of Ideas $66 / 4$, S. 633-650.

Doja, Albert (2006 a): The shoulders of our giants: Claude Lévi-Strauss and his legacy in current anthropology, in: Social Science Information 45 / 1, S. 79-107.

Doja, Albert (2006 b): The kind of writing: anthropology and the rhetorical reproduction of post-modernism, in: Critique of Anthropology 26 / 2, S. 157-180.

Doja, Albert (2006c): The predicament of heroic anthropology, in: Anthropology Today $22 / 3$, S. $18-22$.

Doja, Albert (2006d): A political history of Bektashism from Ottoman Anatolia to Contemporary Turkey, in: Journal of Church and State 48 / 2, S. 421-450.

Doja, Albert (2006 e): A political history of Bektashism in Albania, in: Totalitarian Movements and Political Religions 7 / 1, S. 83-107.

Doja, Albert (2006f): Spiritual surrender: from companionship to hierarchy in the history of Bektashism, in: Numen: International Review for the History of Religions 53 / 2, S. 448-510.

Doja, Albert (2007): Creative misreading and bricolage writing: A structural appraisal of a poststructuralist debate, in: Portuguese Review of the History of the Book 11 / 22, S. 89-104.

Doja, Albert (2008 a): Claude Lévi-Strauss at his Centennial: toward a future anthropology, in: Theory, Culture \& Society 25 / 7-8, S. 321-340.

Doja, Albert (2008b): From Neolithic Naturalness to Tristes Tropiques: the emergence of LéviStrauss's new humanism, in: Theory, Culture \& Society 25 / 1, S. 77-100.

Doja, Albert (2010 a): Claude Lévi-Strauss (1908-2009): The apotheosis of heroic anthropology, in: Anthropology Today 26 / 5, S. 18-23.

Doja, Albert (2010 b): Fertility trends, marriage patterns and savant typologies in Albanian context, in: Journal of Family History 35 / 4, S. 346-367.

Doja, Albert (2013 a): Invitation au terrain: Mémoire personnel de la construction du projet socio-anthropologique, Bruxelles.

Doja, Albert (2013 b): The politics of religious dualism: Naim Frashëri and his elective affinity to religion in the course of 19th-century Albanian activism, in: Social Compass: International Review of Sociology of Religion 60 / 1, S. 115-133.

Doja, Albert (2014): From the German-speaking point of view: Unholy Empire, Balkanism, and the culture circle particularism of Albanian studies, in: Critique of Anthropology 34 / 3, S. 290-326.

Doja, Albert (2015): From the native point of view: An insider / outsider perspective on folkloric archaism and modern anthropology in Albania, in: History of the Human Sciences 28 / 1 (forthcoming).

Dostal, Walter (1994): Silence in the darkness: German ethnology during the National Socialist Period, in: Social Anthropology: Journal of the European Association of Social Anthropologists $2 / 3$, S. 251-262.

Dow, James R. / Hannjost Lixfeld (eds) (1994): The Nazification of an academic discipline: Folklore in the Third Reich, Bloomington / IN.

Durham, Edith ([1909]1994): High Albania, London.

Emmerich, Wolfgang (1968): Germanistische Volkstumsideologie: Genese und Kritik der Volksforschung im Dritten Reich, Tübingen. 
Fabian, Johannes ([1983]2002): Time and the other: how anthropology makes its object, New York / NY.

Feichtinger, Johannes / Ursula Prutsch / Moritz Csáky (eds) (2003): Habsburg postcolonial: Machtstrukturen und kollektives Gedächtnis, Innsbruck.

Fischer, Hans (1990): Völkerkunde im Nationalsozialismus: Aspekte der Anpassung, Affinität und Behauptung einer wissenschaftlichen Disziplin, Berlin.

Gefou-Madianou, Dimitra (1993): Mirroring ourselves through western texts: The limits of an indigenous anthropology, in: Henk Driessen (ed.), The Politics of ethnographic reading and writing: confrontations of Western and indigenous views, Saarbrücken, S. 160-181.

Gerndt, Helge (ed.) (1987): Volkskunde und Nationalsozialismus. München: Münchner Vereinigung für Volkskunde [Cf. Helge Gerndt (1995): Deutsche Volkskunde und Nationalsozialismus: was haben wir aus der Geschichte gelernt, in: Schweizerisch Archiv für Volkskunde 91, S. 53-75].

Gingrich, Andre (2005): The German-Speaking Countries - Ruptures, Schools, and Nontraditions: Reassessing the History of Sociocultural Anthropology in Germany, in: Chris M. Hann (ed.), One discipline, four ways: British, German, French, and American anthropology, Chicago / IL, S. 59-153.

Goldsworthy, Vesna (1998 [2012]): Inventing Ruritania: the imperialism of the imagination, New Haven / CN.

Gostentschnigg, Kurt (1999): Die Verflechtung von Wissenschaft und Politik am Beispiel der österreichisch-ungarischen Albanologie, in: Südost-Forschungen: Internationale Zeitschrift für Geschichte, Kultur und Landeskunde Südosteuropas 58, S. 221-245.

Gostentschnigg, Kurt (2006): Die Frage der albanischen Ethnogenese: Ein historischer Abriss ihrer Diskussion bis zum Ende des 20. Jahrhunderts, in: Grazer Linguistische Studien 66, S. 39-60.

Greenfeld, Liah (1992): Nationalism: five roads to modernity, Cambridge / MA.

Gruber, Siegfried (1998): Austrian contributions to the ethnological knowledge of the Balkans since 1850, in: Ethnologia Balkanica: Journal for Southeast European Anthropology 2, S. 209-224.

Haberlandt, Arthur (1917): Kulturwissenschaftliche Beiträge zur Volkskunde von Montenegro, Albanien und Serbien: Ergebnisse einer Forschungsreise in den von den k.u.k. Truppen besetzten Gebieten, Sommer 1916, Wien: Verein für Österreichische Volkskunde (Zeitschrift für österreichische Volkskunde 23).

Hanbury-Tenison, Robin ([2009]2013): Land of Eagles: riding through Europe's forgotten country, London.

Hann, Chris M. / Mihaly Sarkany / Peter Skalnik (eds) (2005): Studying Peoples in the People's Democracies: socialist era anthropology in East-Central Europe, Berlin - Münster.

Hauschild, Thomas (eds) (1995): Lebenslust und Fremdenfurcht: Ethnologie im Dritten Reich, Frankfurt / Main.

Hemming, Andreas (2012): German-speaking travel writers in interwar Albania, in: Andreas Hemming / Gentiana Kera / Enriketa Pandelejmoni (eds), Albania: family, society and culture in the 20th century, Münster, S. 115-129.

Herzfeld, Michael (1987): Anthropology through the looking-glass: critical ethnography in the margins of Europe, Cambridge.

Herzfeld, Michael (2002): The Absent Presence: Discourses of Crypto-Colonialism, in: South Atlantic Quarterly 101 / 4, S. 899-926.

Heyden, Ulrich van der (2005): Africanist Anthropology in the German Democratic Republic, in: Hann / Sarkany / Skalnik 2005, S. 303-330.

Hobsbawm, Eric / Terence Ranger (eds) (1983): The invention of tradition, Cambridge.

Jacobeit, Wolfgang (2005): The Genesis of Volkskunde in the German Democratic Republic, in: Hann / Sarkany / Skalnik 2005, S. 183-190. 
Johler, Reinhard / Christian Marchetti / Monique Scheer (eds) (2010): Doing anthropology in wartime and war zones: World War I and the cultural sciences in Europe, Bielefeld.

Kaser, Karl (1992): Hirten, Kämpfer, Stammeshelden: Ursprünge und Gegenwart des Balkanischen Patriarchats, Wien.

Kaser, Karl (2002): Albania: Orientalisation and Balkanisation of a Balkan country - A contribution to a ongoing debate, in: Frank Kressing / Karl Kaser (eds), Albania, a country in transition: aspects of changing identities in a South-East European country, Baden-Baden, S. 27-38.

Kaser, Karl (2008): Patriarchy after patriarchy: gender relations in Turkey and in the Balkans, 1500-2000, Berlin - London.

Kaser, Karl / Siegfried Gruber / Robert Pichler (eds) (2003): Historische Anthropologie im südöstlichen Europa: eine Einführung, Wien.

Kiossev, Alexander (2011): The Self-Colonizing Metaphor, in: Atlas of Transformation, abrufbar unter: $\mathrm{http}: / /$ monumenttotransformation.org/atlas-of-transformation/ $\mathrm{html} / \mathrm{s} / \mathrm{self}$-colonization/the-self-colonizing-metaphor-alexander-kiossev.html [8.9.2014].

Krasztev, Peter (2002): The price of amnesia: interpretations of vendetta in Albania, in: Journal for Politics, Gender and Culture 1/2, S. 33-63.

Leach, Edmund (1961): Rethinking anthropology, London.

Lévi-Strauss, Claude ([1955]1973): Tristes Tropiques, Nouvelle edition, Paris.

Linimayr, Peter (1994): Wiener Völkerkunde im Nationalsozialismus: Ansätze zu einer NS-Wissenschaft, Frankfurt / Main.

Lixfeld, Hannjost (1994): Folklore and fascism: the Reich Institute for German Volkskunde, edited by James R. Dow, Bloomington / IN.

Marashi, Ardian / Albert Rakipi (eds) (2013): Shqipëri-Austri: Reflektim Historiografik (Proceedings of Scientific Conferences: Shkodra, May 2012, Tirana, October 2012), Tirana (Botimet Albanologjike).

Marchetti, Christian (2013): Balkanexpedition: die Kriegserfahrung der österreichischen Volkskunde: eine historisch-ethnographische Erkundung, Tübingen.

Matzinger, Joachim (2009): Die Albaner als Nachkommen der Illyrer aus der Sicht der historischen Sprachwissenschaft, in: Schmitt / Frantz 2009, S. 13-36.

Mohrmann, Ute (2005): Volkskunde in the German Democratic Republic on the Eve of its Dissolution, in: Hann / Sarkany / Skalnik 2005, S. 195-210.

Mommsen, Wolfgang J. ([1977]1980): Theories of imperialism, New York / NY [Orig. Imperialismustheorien: Ein Überblick über die neueren Imperialismusinterpretationen, Göttingen].

Mosen, Markus (1991): Der koloniale Traum: angewandte Ethnologie im Nationalsozialismus, Bonn.

Noack, Karoline / Martina Krause (2005): Ethnographie as a Unified Anthropological Science in the German Democratic Republic, in: Hann / Sarkany / Skalnik 2005, S. 25-54.

Pandolfi, Mariella (2000): L'industrie humanitaire, une souveraneté mouvante et supracoloniale: Réflexion sur l'expérience des Balkans, in: Multitudes 3, S. 97-105.

Pandolfi, Mariella (2005): Albania as terra incognita: Orientalism and the myth of transition in the contemporary Balkans, in: Mauro Peressini / Ratiba Hadj-Moussa (eds), The Mediterranean reconsidered: representations, emergences, recompositions, Gatineau, Québec: Canadian Museum of Civilization 79, S. 171-183.

Penny, H. Glenn / Matti Bunzl (eds) (2003): Worldly provincialism: German anthropology in the age of empire, Ann Arbor / MI.

Promitzer, Christian (2012): Austria and the Balkans: Exploring the role of travelogues in the construction of an area, in: Harald Heppner / Christian Promitzer (eds), Area Studies in a Globalizing World, Münster, abrufbar unter: https://online.uni-graz.at/kfu_online/wbLdb2.downloadDocument?pLst$\mathrm{Nr}=284873 \&$ pLstSchichtNr=8603499\&pDocStoreNr=327139 [8.9.2014]. 
Ramadani, Fehari (2010): Kontributi i Austro-Hungarisë për zhvillimin e arsimit dhe të kulturës shqiptare 1900-1912, Tetova (Macedonia).

Rapper, Gilles de (2006): La 'biographie': parenté incontrôlable et souillure politique dans l'Albanie communiste et post-communiste, in: European Journal of Turkish Studies 4, abrufbar unter: www.ejts.revues.org/pdf/565 [8.9.2014].

Resta, Patrizia (2002): Pensare il sangue: La vendetta nella cultura Albanese, Roma.

Said, Edward (1978): Orientalism, New York / NY.

Sampson, Steven (1996): The social life of projects: importing civil society to Albania, in: Chris M. Hann / Elizabeth Dunn (eds), Civil society: challenging western models, London - New York / NY, S. 122-145.

Schafft, Gretchen E. (2004): From racism to genocide: anthropology in the Third Reich, Urbana / IL.

Schmitt, Oliver J. (2009): Skanderbeg: der neue Alexander auf dem Balkan, Regensburg [Albanian transl. Tirana, 2008].

Schmitt, Oliver J. / Eva Frantz (eds) (2009): Albanische Geschichte: Stand und Perspektiven der Forschung. München [Albanian transl. Tirana, 2012].

Scholze, Thomas (2001): Anmerkungen zur Frühgeschichte des Volkskunde in der sowjetischen Besatzungszone bzw. späteren DDR, in: Thomas Scholze / Leonore Scholze-Irrlitz (eds), Zehn Jahre Gesellschaft für Ethnographie-Europäische Ethnologie in Berlin: Wolfgang Jacobeit zum 80. Geburtstag, Münster, S. 149-156.

Schramm, Gottfried ([1994]1999): Anfänge des albanischen Christentums: Die frühe Bekehrung der Bessen und ihre langen Folgen, 2. Auflage, Freiburg / Breisgau [Albanian transl. St. Gallen, 2006].

Schwandner-Sievers, Stephanie (2008): Albanians, Albanianism and the Strategic Subversion of Stereotypes, in: Anthropological Notebooks (Ljubljana) 14 / 2, S. 47-64.

Skalnik, Peter (2002): West meets East or rather it finds new exotic lands, in: Peter Skalnik (ed.), A Post-Communist Millennium: the struggles for sociocultural anthropology in Central and Eastern Europe, Prague, S. 185-195.

Stocking, George W (1965): On the limits of 'presentism' and 'historicism' in the historiography of the behavioral sciences, in: Journal of the History of the Behavioral Sciences 1 / 3, S. 211-218.

Stocking, George W. (ed.) (1991): Colonial situations: essays on the contextualization of ethnographic knowledge, Madison / WI (History of anthropology 7).

Stocking, George W. (ed.) (1996): Volksgeist as method and ethic: essays on Boasian ethnography and the German anthropological tradition, Madison / WI (History of anthropology 8).

Streck, Bernhard (ed.) (2000): Ethnologie und Nationalsozialismus, Gehren.

Sundhaussen, Holm (1973): Der Einfluss der Herderschen Ideen auf die Nationsbildung bei den Völkern der Habsburger Monarchie, München.

Thalloczy, Ludwig von (ed.) (1916): Illyrisch-Albanische Forschungen, München - Leipzig.

Thörner, Klaus (2008): Der ganze Südosten ist unser Hinterland: deutsche Südosteuropapläne von 1840 bis 1945, Freiburg / Breisgau.

Todorova, Maria (1997): Imagining the Balkans, New York / NY.

Tönnes, Bernhardt (1980): Sonderfall Albanien: Enver Hoxhas eigener Weg und der historischen Ursprünge seiner Ideologie, München.

Treide, Dietrich (2005): Onwards, But in Which Direction? Anthropology at the University of Leipzig between 1950 and 1968, in: Hann / Sarkany / Skalnik 2005, S. 133-158.

Turda, Marius (2013): In search of racial types: soldiers and the anthropological mapping of the Romanian nation, 1914 - 44, in: Patterns of Prejudice 47 / 1, S. 1-21.

Voell, Stephane (2004): Das nordalbanische Gewohnheitsrecht und seine mündliche Dimension, Marburg. 
Wallace, Anthony F.C. (1956): Revitalization movements, in: American Anthropologist 58 / 2, S. 264-281.

Wolff, Larry (1994): Inventing Eastern Europe: the map of civilization on the mind of the enlightenment, Stanford / CA.

Young, Antonia (2000): Women who become men: Albanian sworn virgins, Oxford.

Zimmerman, Andrew (2001): Anthropology and antihumanism in Imperial Germany, Chicago / IL.

Prof. Dr. Albert Doja Institute of Sociology and Anthropology University of Lille

Clersé - UMR CNRS 8019 Cité Scientifique, SH2-205

F-59655 Lille, France albert.doja@univ-lille1.fr 